\title{
EFFECTS OF MINERAL AND ORGANIC-MINERAL PHOSPHATE FERTILIZERS ON SOIL FERTILITY PARAMETERS
}

\author{
Diego Henriques Santos ${ }^{1}$, Carlos Sérgio Tiritan ${ }^{2}$, José Salvador Simoneti Foloni ${ }^{3}$, Luciana Boulhosa Fabris ${ }^{4}$ \\ ${ }^{1}$ Companhia de Desenvolvimento Agrícola de São Paulo - CODASP - Presidente Prudente-SP; ${ }^{2}$ Universidade do Oeste Paulista - \\ UNOESTE - Presidente Prudente-SP; ${ }^{3}$ Empresa Brasileira de Pesquisa Agropecuária - EMBRAPA - Londrina-PR; ${ }^{4}$ Centro Estadual de \\ Educação Tecnológica Paula Souza - Presidente Prudente-SP.
}

\begin{abstract}
Organic sources can replace all or part of the mineral phosphorus used in fertilizer, providing significant changes in soil chemical properties. This research evaluated the effects of mineral and organic-mineral phosphorus on the soil fertility in maize tillage. The experiment was installed in a seedling nursery at Universidade do Oeste Paulista in Presidente Prudente-SP, in a complete randomized blocks design, with 9 treatments (different Biofós doses associated with different superphosphate doses) and 4 replicates. As phosphorus fertilizer source was used the organic-mineral Biofós $\left(3.8 \% \mathrm{P}_{2} \mathrm{O}_{5}\right)$ and simple superphosphate $\left(18 \% \mathrm{P}_{2} \mathrm{O}_{5}\right)$. At 50 days after emergence of corn plants it was held soil sampling vessels for evaluation of phosphorus, organic matter, calcium, magnesium, base saturation and soil pH. The fertilizer organic-mineral showed the same efficiency of simple superphosphate in soil fertility. The organo-mineral fertilizer showed the same efficiency of superphosphate on soil fertility, both of which promoted the same changes in $\mathrm{pH}$. Higher Biofós doses should have high levels of soil organic matter, which was not observed. Phosphorus, calcium, magnesium and base saturation level did not differ in all fertilizer sources and levels used.

Key-words: Zea mays; phosphorus; organic matter.
\end{abstract}

\section{EFEITOS DA ADUBAÇÃO FOSFATADA MINERAL E ORGANOMINERAL NOS PARÂMETROS DE FERTILIDADE DO SOLO}

\section{RESUMO}

Fontes orgânicas podem substituir todo ou parte do fósforo mineral utilizado na adubação, podendo proporcionar alterações significativas nos atributos químicos do solo. O presente trabalho teve por objetivo avaliar os efeitos da adubação fosfatada mineral e organomineral nos parâmetros de fertilidade do solo cultivado com milho. O experimento foi conduzido no viveiro de mudas da Universidade do Oeste Paulista, em Presidente Prudente-SP. Utilizou-se o delineamento experimental em blocos inteiramente casualizados, com 9 tratamentos e 4 repetições. Como fonte de fósforo, utilizou-se o adubo organomineral Biofós (3,8\% de $\left.\mathrm{P}_{2} \mathrm{O}_{5}\right)$ e o Superfosfato Simples $\left(18 \% \mathrm{P}_{2} \mathrm{O}_{5}\right)$. Aos 50 dias após a emergência das plantas de milho, realizou-se amostragem de solo nos vasos para avaliação dos teores de fósforo, matéria orgânica, cálcio, magnésio, saturação por bases e pH do solo. $\mathrm{O}$ fertilizante organomineral apresentou a mesma eficiência do superfosfato simples na fertilidade do solo, sendo que ambos promoveram as mesmas alterações nos valores de $\mathrm{pH}$. As maiores doses de Biofós deveriam ter elevado os níveis de matéria orgânica do solo, o que não ocorreu; enquanto os teores de fósforo, cálcio, magnésio e saturação por bases não se diferenciaram em relação às fontes e doses de adubo utilizado.

Palavras-chave: Zea mays; fósforo; matéria orgânica. 


\section{INTRODUCTION}

Agricultural productivity and sustainability is affected by fertilization. The main factors affecting the availability of phosphorus in soil are organic matter content, the cation exchange capacity (CEC), the buffering capacity, the calcium, iron and aluminum and humidity interfering consequently on plant uptake. This condition provides a reduction in base saturation and soil as a result of the gradual change from source to drain inorganic phosphorus (SANTOS et al., 2011). Therefore, the percentage of recovery of applied phosphorus fertilizer in the agricultural crops is low, between 5 and 20\% (ALCARDE; PROCHNOW, 2004). It is important to remember that phosphorus is a scarce and non-renewable natural resources, and must be efficient used.

In greenhouse evaluation of soluble source of phosphorus realized by Loganathan and Fernando (1980), over $90 \%$ of phosphorus used was adsorbed in the first hour of contact with the soil. Novais (1980) also describe that phosphorus is more soluble and less available for plants as long as it remains in contact with soil.

According to Lopes (1998), phosphorus increases root system growing, enlarging water absorption efficiency by plants, what ensures lower losses and better utilization of other nutrients, promoting plants survival during periods of water stress. Araújo and Sampaio (2010) found that deeper roots absorbed more phosphorus. As phosphorus concentration is low in soil solution and it moves itself to the roots by diffusion, a bigger root system guarantees better absorption of water and consequently of phosphorus. Santos et al. (2012) reports the effects of organic matter in the efficiency of phosphates fertilization. Organic matter increases cation exchange capacity, provides nutrients, improves water retention and soil structure, and interact with clay minerals, ensuring the stability of aggregates, even with the expansion of the clay which directly reduces soil erodibility.

According to Santos et al. (2011), phosphorus deficiency is considered a problem to tropical soils and has an important function in agricultural crops, therefore worthy a large study as soil fertilizer. Although very little leachate, the phosphorus applied to soil reactes to the mineral soil phase, been unvailable to agricultural crops. Nakayama et al. (1998) believes that phosphorus deficiency is one of the factors limiting agricultural production in acid soils because in these soils, water soluble phosphorus is transformed into iron phosphate and aluminum phosphate, which become unavailable to plants.

According to Santos et al. (2010), organic sources can replace all or part of the phosphorus applied to agricultural crops, providing significant changes in chemical soil, increasing macro and micronutrients availability, organic carbon levels, improving soil physical structure, and increasing soil water capacity retention. In this sense, the objective of this study was to evaluate the effects of phosphate mineral fertilization and phosphate organic-mineral phosphorus fertilization on the chemical and fertility properties of a soil cultivated with maize.

\section{MATERIALS AND METHODS}

The experiment was carried in the seedling nursery of UNOESTE - Universidade do Oeste Paulista (latitude $22^{\circ} 07^{\prime} 30^{\prime \prime}$ South and longitude $51^{\circ} 26^{\prime} 00^{\prime \prime}$ West) in pots of 20 liters, during a period of 50 days, between the months of August and November of 2008. The climate of the area is classified as Cwa, according to Köppen. It was used a soil from Álvares Machado city, São Paulo State, Brasil, classified as Yellow Red Argisol sandy, according to Embrapa (2006). Samples were collected for characterization of chemical attributes (RAIJ et al., 2001) with the following results: $\mathrm{pH}\left(\mathrm{CaCl}_{2} 1 \mathrm{~mol} \mathrm{~L}^{-1}\right) 5.2 ; 11 \mathrm{~g}$ 
$\mathrm{dm}^{-3}$ of $\mathrm{OM}$ (organic matter); $12 \mathrm{mg} \mathrm{dm}^{-3}$ of $\mathrm{P}_{\text {resin }}$; $21 \mathrm{mmol}_{\mathrm{c}} \mathrm{dm}^{-3}$ of $\mathrm{H}+\mathrm{Al} ; 3.4 \mathrm{mmolc} \mathrm{dm}^{-3}$ of $\mathrm{K} ; 15$ $\mathrm{mmol}_{\mathrm{C}} \mathrm{dm}^{-3}$ of $\mathrm{Ca} ; 10 \mathrm{mmol}_{\mathrm{C}} \mathrm{dm}^{-3}$ of $\mathrm{Mg} ; 28 \mathrm{mmol}_{\mathrm{C}}$ $\mathrm{dm}^{-3}$ of SB; $49 \mathrm{mmol}_{\mathrm{c}} \mathrm{dm}^{-3}$ of CEC; $58 \%$ of base saturation $(\mathrm{V})$.

The liming was made 30 days before maize sowing, after soil screening, trying to elevate the base saturation for $70 \%$, being used a dolomitc lime roasted with $100 \%$ of ECC $(32 \%$ $\mathrm{CaO}$ and $18 \% \mathrm{MgO})$. After the incubation period limestone, the soil received the minimum planting manuring, accomplished in agreement with Raij et al. (1997), being $240 \mathrm{Kg} \mathrm{ha}^{-1}$ of $\mathrm{N}(4.4 \mathrm{~g}$ of urea per pots) and $280 \mathrm{Kg} \mathrm{ha}{ }^{-1}$ of $\mathrm{K}_{2} \mathrm{O}(4.0 \mathrm{~g}$ of potassium chloride per pot), just varying the phosphorus doses according to the experimental design. Maize was cultivated by two cycles in these pots. The third sowing (Bayer Seeds Hybrid) was accomplished using five seeds per pots. The beginning of the emergency of the seedlings happened five days after the sowing, and three days after the emergency (DAE) it was conducted a thinning, maintaining only two plants per pot. Humidity of the soil was maintained close to the field capacity of the soil $\left(180 \mathrm{~g}^{\mathrm{kgg}}{ }^{-1}\right.$ of water), through water daily.

The experimental design was a complete randomized blocks, with 9 treatments and 4 replicates. As phosphorus source, the fertilizer organic-mineral Biofós was used $\left(3,8 \%\right.$ of $\left.\mathrm{P}_{2} \mathrm{O}_{5}\right)$ and simple superphosphate $\left(\begin{array}{lll}18 \% & \mathrm{P}_{2} \mathrm{O}_{5}\end{array}\right)$. Treatments are described in Table 1, calculated based on the volume of soil.
Table 1. Treatments with different combinations of superphosphate and biofós, according to the experimental design, in kilograms per hectare and the equivalent in grams per pot.

\begin{tabular}{c|c|c|c|c}
\hline \multirow{2}{*}{ Treatments } & \multicolumn{2}{|c|}{ Biofós } & \multicolumn{2}{c}{$\begin{array}{c}\text { Simple } \\
\text { Superphosphate }\end{array}$} \\
\cline { 2 - 5 } & $\begin{array}{c}(\mathrm{kg} \\
\left.\mathrm{ha}^{-1}\right)\end{array}$ & $\begin{array}{c}\left(\mathrm{g} \cdot \mathrm{pots}^{-}\right. \\
1\end{array}$ & $\begin{array}{c}\left(\mathrm{kg} \mathrm{ha}^{-}\right. \\
\text {of } \\
\left.\mathrm{P}_{2} \mathrm{O}_{5}\right)\end{array}$ & $\left(\right.$ g.pots $\left.^{-1}\right)$ \\
\hline 01 - control & 0 & 0 & 0 & 0 \\
\hline 02 & 0 & 0 & 30 & 1.1 \\
\hline 03 & 600 & 5.0 & 0 & 0 \\
\hline 04 & 0 & 0 & 60 & 2.2 \\
\hline 05 & 1200 & 10.0 & 0 & 0 \\
\hline 06 & 0 & 0 & 90 & 4.4 \\
\hline 07 & 2400 & 20.0 & 0 & 0 \\
\hline 08 & 0 & 0 & 120 & 6.6 \\
\hline 09 & 3600 & 30.0 & 0 & 0 \\
\hline
\end{tabular}

The soil sampling in the pots for chemical characterization took place at 45 days after the emergency (DAE) of the maize plants, following methodology of Raij et al. (2001). Phosphorus levels were analyzed, organic matter, calcium, magnesium, saturation for bases, $\mathrm{pH}$, total porosity and real soil density.

The data were submitted to the variance analysis and regression, besides a study of mean test (Tukey to $5 \%$ of probability) for the variables that presented statistical difference.

\section{RESULTS AND DISCUSSION}

The referring results to the phosphorus tenors in the soil are in the Figure 1. It was verified that the phosphorus levels in the soil didn't present response to the doses of applied $\mathrm{P}_{2} \mathrm{O}_{5}$ in the sowing. It is worth to remind that these results were obtained after the third successive maize cultivation, therefore the nutrients were extracted for the culture during three consecutive cycles.

It is possible that, to produce, the plant consumes nutrients coming of the fertilizer, besides part of the soil nutrients, resulting therefore in reduction of the phosphorus levels in 
the soil. When comparing the results of the simple superphosphate and of Biofós, it is verified that phosphorus levels found in the soil are larger in the treatments with Biofós. Despite Biofós provide lower amounts of phosphorus in its composition when compared to superphosphate, this product contains organic matter, not present in the mineral fertilizer. To increase the efficiency of phosphorus, reducing the doses used, Santos et al. (2010) recommend the use of a charger to bulk organic to protect the phosphorus of the fixation, especially in areas that have been cultivated with grass for a long period. Such result was not waited, once the used fertilizers contain reasonable amounts of $\mathrm{P}_{2} \mathrm{O}_{5}$, ally to the fact that the anion phosphate is very little movable in the soil, being also little extracted for the culture (FANCELLI; DOURADO NETO, 2000). An increase in the phosphorus tenors in the soil it was also cited by Gomes et al. (2005).

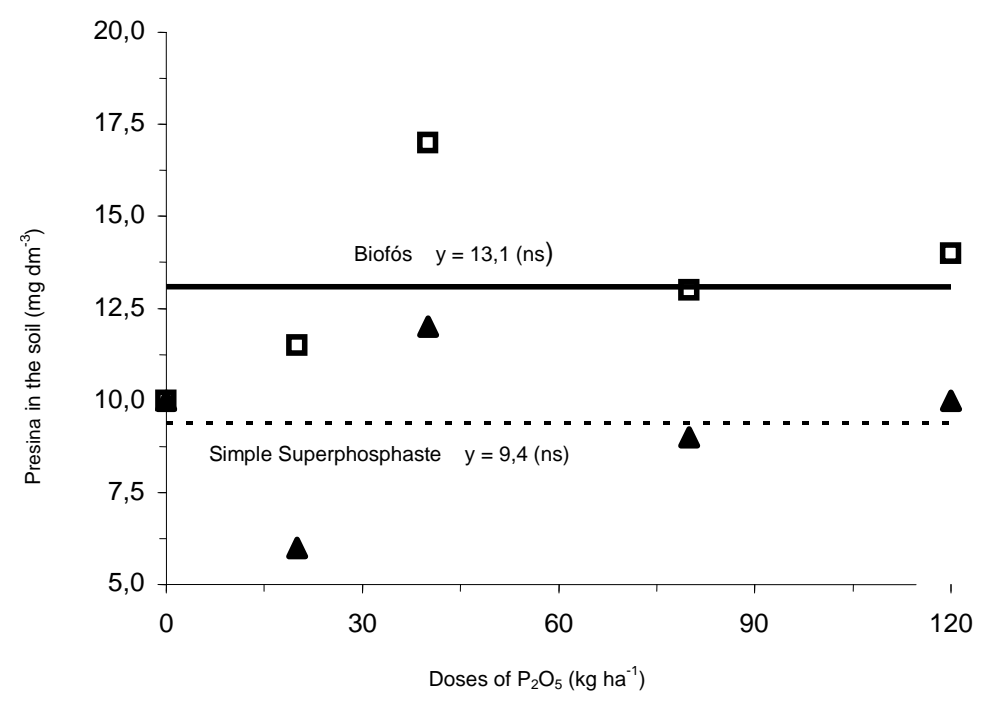

Figure 01. Soil phosphorus levels in function of the applied treatments.

The results of soil $\mathrm{pH}$ in function of the mineral and organic-mineral phosphate fertilizer are in the Figure 2. It was verified that the values of $\mathrm{pH}$ of the soil answered to the applied phosphorus doses, with quadratic fitting for simple superphosphate doses and positive linear fitting for Biofós doses.

The results of soil calcium levels in function of the $\mathrm{P}_{2} \mathrm{O}_{5}$ doses are in the Figure 3. It was verified that the tenors of calcium didn't present response to the doses of applied $\mathrm{P}_{2} \mathrm{O}_{5}$, in other words, the soil calcium tenors were the same, independent of the doses variation and phosphorus source. However, it should be pointed out that these results were obtained after the third successive maize cultivation, therefore there was extraction of calcium for the culture during three consecutive cycles, as already mentioned for the phosphorus levels, what perhaps had not allowed to verify an increment of calcium in the proportionate soil for the organic manuring, as reported by Santos et al. (2010). 


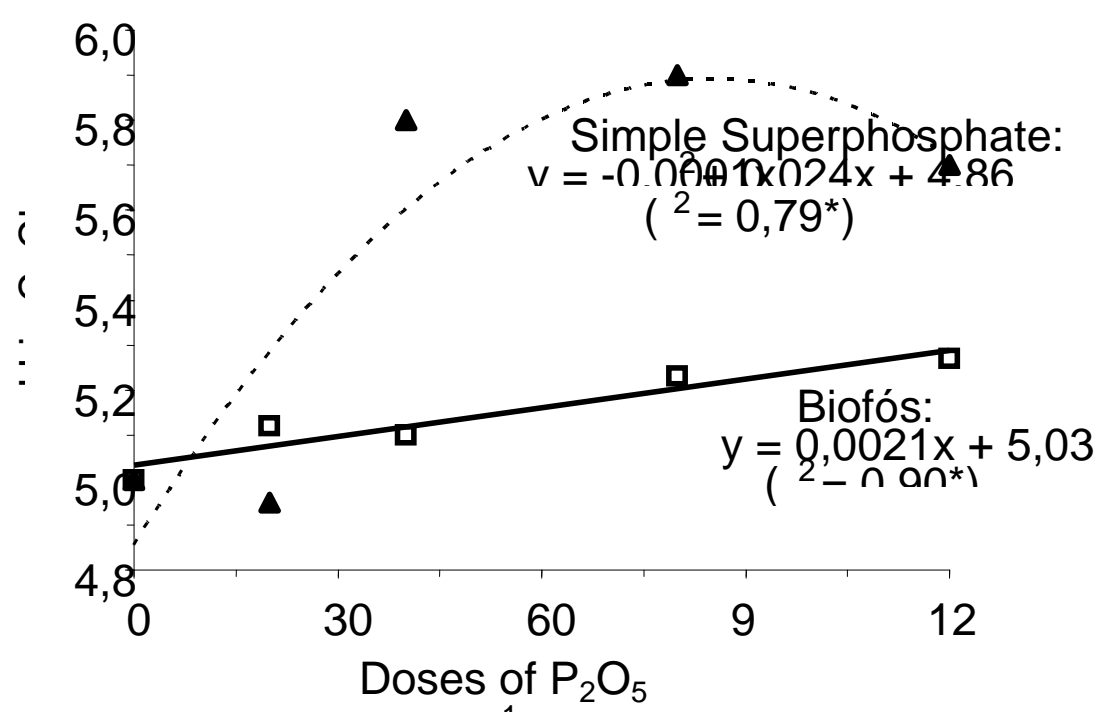

Figure 02. Soil pH in function of the applied treatments.

In relation to the levels of exchangeable $\mathrm{Ca}^{+2}$ in the soil, Gomes et al. (2005), also working with maize tillage, observed an higher effect of the organic manuring than of the mineral manuring, as well as of the interaction between such factors. Additionally, the doses increase of the mineral fertilizer resulted in linear reduction of the $\mathrm{Ca}^{+2}$ levels in the soil.

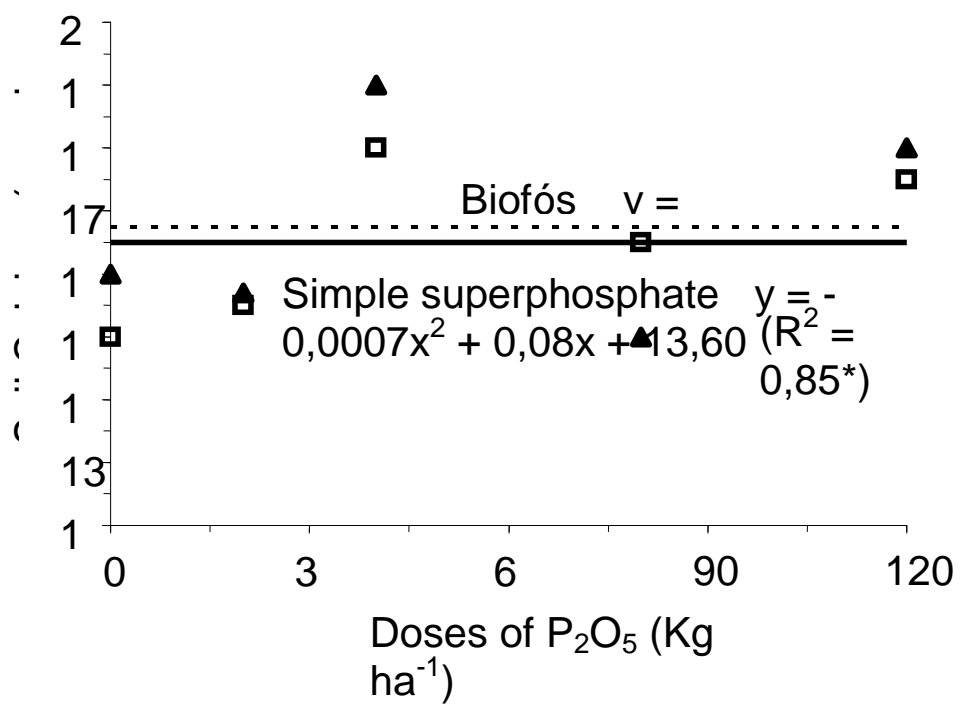

Figure 03. Soil calcium tenors in function of the applied treatments.

The results of soil organic matter are in the Figure 04. It was verified that the tenors of soil organic matter presented quadratic adjustment for the doses, independent of the sources of phosphatade fertilizer used. The largest tenors of soil organic matter were not obtained with the largest doses of Biofós in the sowing. For that result was not waited, because the organic manurings usually result in elevation of the organic carbon level in the soil (MALAVOLTA, 1981). The largest Biofós doses should have elevated the soil organic matter levels, although the amounts of organic matter added to the soil through the Biofós it is very small. Gomes et al. 
(2005) founded a linear crescent answer of the organic manuring levels. total carbon organic of the soil in function of

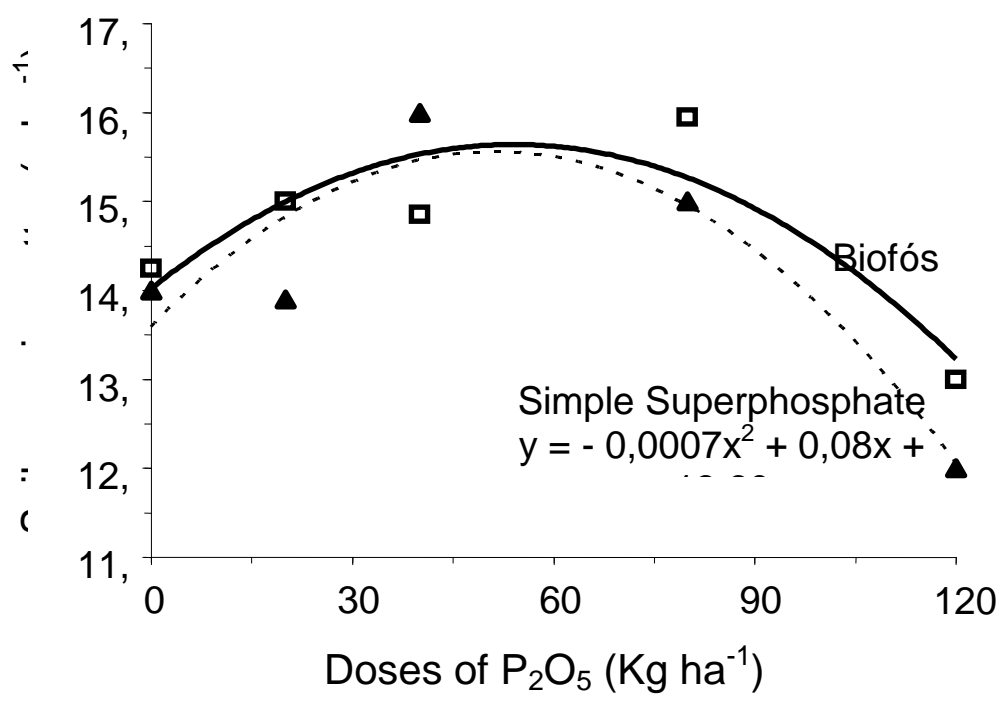

Figure 04. Soil organic matter tenors in function of the applied treatments.

The base saturation (V\%) results of the submitted soil the manuring mineral phosphatade and organic-mineral are presented in the Figure 05. It was verified that the values of soil base saturation didn't present answer to the applied doses. Comparing the simple superphosphate and Biofós results, it is verified that base saturation soil tenors are statistically same.

The results of soil magnesium tenors are in the Figure 06. It was verified that the soil magnesium tenors didn't present answers to the applied doses. Comparing the results of the simple superphosphate and of the Biofós, it was verified that the tenors of magnesium in the soil were same statistically. These results go against those introduced by Holanda et al. (1984) and Gomes et al. (2005), that observed elevation of $\mathrm{Mg}^{+2}$ and $\mathrm{K}^{+}$tenors with the increase of the doses of organic manuring.

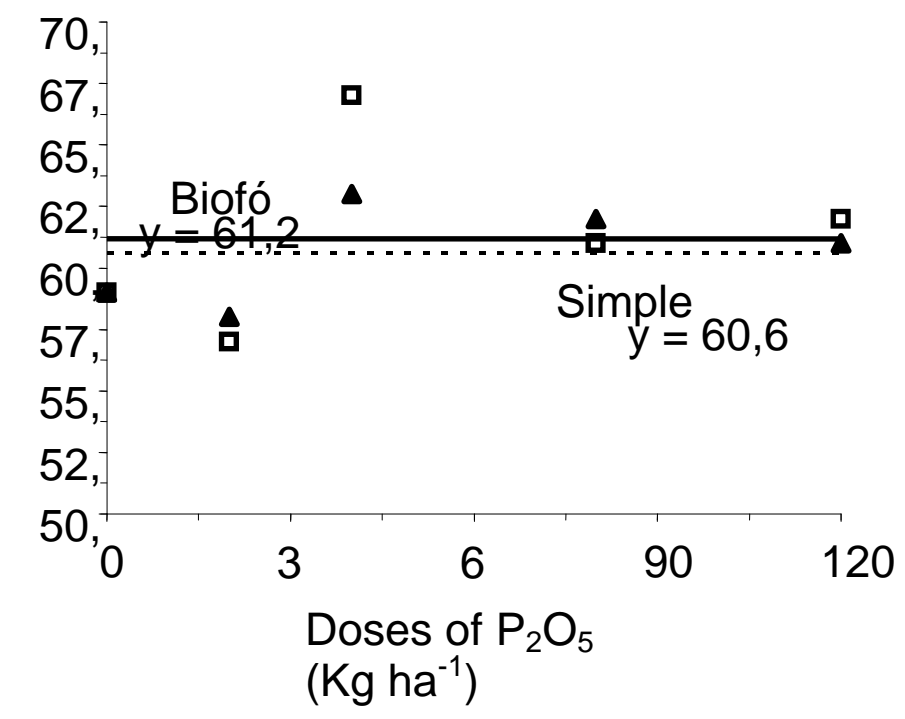

Figure 05 . Soil base saturation tenors in function of the applied treatments. 
In relation to the soil physics characteristics, the results of the variance analysis revealed that the variables total porosity and real and apparent soil density were not altered significantly in relation to the applied treatments. This result can be explained because there were not expressive alterations in the levels of organic matter, and, according to Marcolin and Klein (2011), this is an important factor that affects the soil density. This evaluation is of great importance because the principal process of phosphorus movement in the soil is by diffusion. As the movement of the phosphorus for diffusion to the roots of the plants is restricted, that process is usually considered as limiting factor in your absorption (GRANT et al., 2001). Due to the low mobility of the phosphorus its absorption can still be more committed in compacted soils, due to the fact of the soil mechanical resistance reduces the ability of the roots in phosphorus absorbing, as it is the maize case (FOLONI et al., 2003).

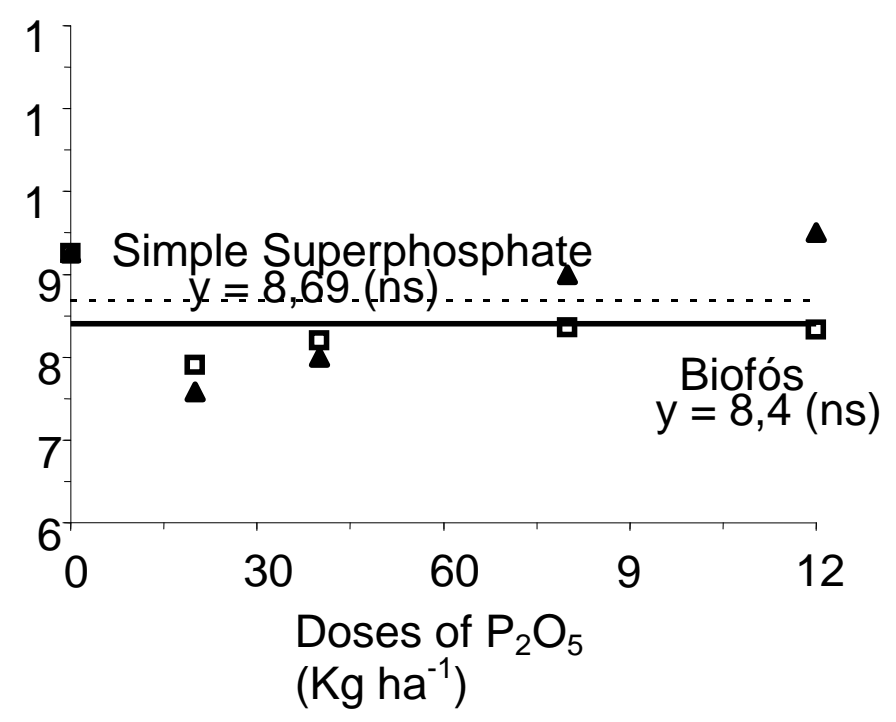

Figure 06. Soil magnesium tenors in function of the applied treatments.

\section{CONCLUSION}

The organic-mineral fertilizer, Biofós, presented the same behavior of the simple superphosphate in the soil fertility parameters. The two phosphorus sources promoted alterations in the $\mathrm{pH}$ values, however without altering the levels of soil organic matter. It was concluded that both ferlizers didn't interfere in the real and apparent density and in the total porosity of the soil.

\section{REFERENCES}

ALCARDE, J.C.; PROCHNOW, L.I. Metodologias de extração química para avaliação da eficiência de fertilizantes fosfatados. In: YAMADA, T.;
ABDALLA, S.R.S. (Eds.). Simpósio sobre fósforo na agricultura brasileira, 2004. São Pedro-SP. Anais... São Paulo: Associação Brasileira para Pesquisa da Potassa e do Fosfato, 2004. p.589603.

ARAÚJO, M.S.B.; SAMPAIO, E.V.S.B. Distribuição e caracterização de fósforo em solos de ecossistemas nativos úmido e semi-árido. Revista de Geografia, v.27, n.22, p.141-154, 2010.

EMBRAPA. Empresa Brasileira de Pesquisa Agropecuária. Centro Nacional de Pesquisa de Solos. Sistema Brasileiro de Classificação de Solos. 2. ed. Rio de Janeiro: Embrapa, 2006.

FANCELLI, A.L.; DOURADO NETO, D. Produção de milho. Guaíba: Agropecuária, 2000. 
FOLONI, J.S.S.; CALONEGO, J.C.; LIMA, S.L. Efeito da compactação do solo no desenvolvimento aéreo e radicular de cultivares de milho. Pesquisa Agropecuária Brasileira, v.38, n.8, p.947-955, 2003 http://dx.doi.org/10.1590/S0100-

204X2003000800007.

GRANT, C.A.; FLATEN, D.N.; TOMASIEWICZ, D. J.; SHEPARD, S.C. A importância do fósforo no desenvolvimento inicial da planta. Piracicaba: POTAFOS, 2001. (n.95)

GOMES, J.A.; SCAPIM, C.A.; BRACCINI, A.L.; VIDIGAL FILHO, P.S.; SAGRILO, E.; MORA, F. Adubações orgânica e mineral, produtividade do milho e características físicas e químicas de um Argissolo Vermelho-Amarelo. Acta Scientiarum Agronomy, v.27, n.3, p.521-529, 2005. http://dx.doi.org/10.4025/actasciagron.v27i3.1472.

HOLANDA, J.S.; TORRES FILHO, J.; BEZERRA NETO, F. Alterações na fertilidade de dois solos adubados com esterco de curral e cultivados com caupi. Revista Brasileira de Ciência do Solo, v.8, n.1, p.301-304, 1984.

LOGANATHAN, P.; FERNANDO, W.T. Phosphorus absorption by some coconut growing acid soils of Sri Lanka and its relationship to selected soil properties. Journal of the Science of Food and Agriculture, v.31, n.1, p.709-717, 1980.

LOPES, A.S. Manual de fertilidade do solo. 2. ed. Piracicaba: POTAFOS, 1998.

MALAVOLTA, E. Manual de química agrícola: adubos e adubação. 3. ed. São Paulo: Editora Agronômica Ceres, 1981.

MARCOLIN, C.D.; KLEIN, V.A. Determinação da densidade relativa do solo por uma função de pedotransferência para a densidade do solo máxima. Acta Scientiarum Agronomy, v.33, n.2, p.349-354, 2011. http://dx.doi.org/10.4025/actasciagron.v33i2.6120.

NAKAYAMA, L.H.I.; CACERES, N.T.; ALCARDE, J.C.; MALAVOLTA, E. Eficiência relativa de fontes de fósforo de diferentes solubilidades na cultura do arroz. Scientia Agricola, v.55, n.2, p.183-190, $1998 . \quad$ http://dx.doi.org/10.1590/S010390161998000200003

NOVAIS, R.F. Efeito do tempo de incubação do fosfato de araxá em solos sobre o fósforo disponível. Revista Brasileira de Ciência do Solo, v.4, n.1, p.153-155, 1980.

RAIJ, B.; ANDRADE, J.C.; CANTARELLA, H.; QUAGGIO, J.A. Análise química para avaliação da fertilidade de solos tropicais. Campinas: Instituto Agronômico, 2001.

RAIJ, B.; CANTARELLA, H.; QUAGGIO, J.A.; FURLANI, A.M.C. (Ed.) Recomendações de adubação e calagem para o Estado de São Paulo. 2. ed. Campinas: IAC, 1997. (Boletim Técnico, 100).

SANTOS, D.H.; SILVA, M.A.; TIRITAN, C.S.; FOLONI, J.S.S.; ECHER, F.R. Qualidade tecnológica da cana-de-açúcar sob adubação com torta de filtro enriquecida com fosfato solúvel. Revista Brasileira de Engenharia Agrícola e Ambiental, v.15, n.5, p.443-449, 2011. http://dx.doi.org/10.1590/S141543662011000500002.

SANTOS, D.H.; TIRITAN, C.S.; FOLONI, J.S.S. Efeito residual da adubação fosfatada e torta de filtro na brotação de soqueiras de cana-deaçúcar. Revista Agrarian, v.5, n.15, p.1-6, 2012.

SANTOS, D.H.; TIRITAN, C.S.; FOLONI, J.S.S.; FABRIS, L.B. Produtividade de cana-de-açúcar sob adubação com torta de filtro enriquecida com fosfato solúvel. Pesquisa Agropecuária Tropical, v.40, n.4, p.454-461, 2010. http://dx.doi.org/10.5216/pat.v40i4.7272 